\title{
ECONOMIC ACTIVITY OF ENTERPRISES OF THE TELECOMMUNICATION INDUSTRY IN CONDITIONS OF IMPLEMENTATION OF THE NEWEST TECHNOLOGIES
}

\author{
Lyubov Striy', Vasiliy Orlov², Lolita Zakharchenko³
}

\begin{abstract}
The purpose of the article is to present the results of research on the direction of changing the content and forms of economic activity of telecommunication enterprises in the process of introducing the newest technologies. The article also proposes a micro model of one of the possible options for increasing the effectiveness of the economic activity of an enterprise by organizing its effective interaction with all participants of the telecommunication market. The study was performed on the example of communication enterprises operating in the communication space of Ukraine. Since the current markets for communication services integrated with the cyberspace of the Internet are virtually global, it can be assumed that the results are typical for other communication spaces. Methodology. Theoretical and methodological basis of the research are monographs, scientific books, scientific articles of modern scientists in the field of telecommunications, the newest information and communication technologies, economic globalization, development of the Internet. The basic documents that form the basis for analysing the performance of telecommunications enterprises are statistical data of the State Statistics Service of Ukraine. Other available Internet publications have also been used. To ensure the validity of research results, the following methods were used: survey methods for clarifying concepts; economic-statistical and method of graphic representation in the study of directions of changes in economic activity of telecommunications enterprises in Ukraine; economic modelling, in particular, the heuristic anaxiomatization approach, in the development of micro models of cooperation of the communication enterprise with other market actors in the process of economic activity, and some others. Results. The conducted researches confirmed the assumption that there is a redistribution of incomes during the introduction of the newest technologies in the economic activity of telecommunication enterprises. The share of revenues from the provision of telecommunications services is declining, the share of revenues from the provision of Internet services is increasing. To increase the effectiveness of economic activities of telecommunications enterprises, a micro model of cooperation has been developed and justified by the enterprise of communication with other market players in the process of economic activity. Practical importance. The micro model of interaction reflects the actual structure of interaction between telecommunications enterprises and all participants in the global telecommunications market. Practical implementation of the model can contribute to increasing the efficiency of the economic activity of telecommunications enterprises in the context of the introduction of new technologies. The model can also be used by other researchers to study various aspects of economic activity in the real market where telecommunication companies operate. Value/ originality. The originality of the results lies in a detailed study of real trends of changes in the content of economic activity of telecommunication enterprises in the context of introducing new technologies, and in the development of a micro model for the interaction of the telecommunications enterprise with all other market players.
\end{abstract}

Key words: global market, economic activity, economics integration, internet services, infocommunications services, micro models of cooperation, survey methods, telecommunications.

JEL Classification: C42, F15, L96, 012

\footnotetext{
Corresponding author:

${ }^{1}$ O.S. Popov Odessa National Academy of Telecommunications, Ukraine.

E-mail: striyla@ukr.net

ORCID: http://orcid.org/0000-0003-4683-1806

${ }^{2}$ O.S. Popov Odessa National Academy of Telecommunications, Ukraine.

E-mail: orlov_vn@ukr.net

ORCID: http://orcid.org/0000-0001-6392-5500

${ }^{3}$ O.S. Popov Odessa National Academy of Telecommunications, Ukraine.

E-mail: onat.iem@gmail.com

ORCID: http://orcid.org/0000-0001-5551-1148
} 


\section{Introduction}

The introduction of the newest mobile communication technologies, broadband fixed technologies significantly expands enterprises communication capabilities. Further development of information technologies contributes to the creation of new information products, a significant increase in the capabilities of the global cyberspace of the Internet and its use in the economic activities of enterprises. The convergence of information and communication technologies allows us to continuously create and improve new infocommunication services that can meet the growing information needs of modern people. These factors stimulate the development of global markets for new and up-to-date services (communication services, information services, Internet services and others, which are integrated into the concept of "infocommunication services"). The economic activity of communication enterprises in the process of introducing new technologies is becoming different. In particular, there is a redistribution of income of the enterprise from the provision of telecommunications services to the provision of Internet services, as well as the provision of information services. However, the problem, the relevance of which is continuously increasing, practically is not studied by specialists, which leads to the feasibility of its research and publication of this article.

Literature review. One can single out several works published in recent years, where some possible aspects of solutions to this problem are described. The influence of the developing Fourth Industrial Revolution on the change in the economic activity of enterprises is described by the Swiss economist K. Schwab. K. Schwab, summarizing the experience and views of the world's leading experts, as well as the leaders of the largest corporations, outlined the scientific analysis of the directions of this revolution in the book "The Fourth Industrial Revolution". According to the author, the newest technologies can synthesize new more advanced and more efficient technologies. In addition, a staggering combination of technological breakthroughs is possible in a wide range of areas (Schwab, 2016). F. Kotler \& L. Keller explored in their popular book some aspects of this problem, in particular, the choice of effective working strategies in the modern market (Kotler \& Keller, 2014). P. Drucker investigated the impact of new technologies in the 21st century on any industry (Drucker, 2007). M. Castells in his monograph described the impact of the information technology revolution on economic development (Castells, 2000). In the monograph of T. Kuzovkova, L. Tymoshenko considered the requirements of the economy for infocommunication infrastructure, the laws of the infocommunication industry development (Kuzovkova, Tymoshenko, 2016). The authors of the monograph "Economy and Management of the Enterprise: the Main Trends and Problems of Development" explored the functionality of the infocommunication services markets, possible directions for improving the economic activity of infocommunication enterprises (Golubev, Striy, Zakharchenko, 2015). The current state, development trends, and organization of economic activity of telecommunications enterprises in modern conditions are considered in the articles: A. Kling "What is Economic Activity?" (Kling, 2011); L. Zakharchenko "Model of the Process of Economic Activity of a Modern Enterprise" (Zakharchenko, 2014); L. Stryi "Global Economy: the Current State of Global Markets" (Stryi, 2016). However, among many publications about the analysis of the economic activity of telecommunications enterprises, there are practically no works about the impact of the introduction of new technologies on the efficiency of economic activity.

The methodology of the research. Theoretical and methodological basis of the research are monographs, scientific books, scientific articles of modern scientists in the field of telecommunications, the newest information and communication technologies, economic globalization, development of the Internet. To ensure the validity of research results, the following methods were used: survey methods for clarifying concepts; economic-statistical and method of graphical representation in the study of the direction of changes in economic activity of telecommunications enterprises in Ukraine; economic modelling, in particular, the heuristic anaxiomatization approach, in the development of micro models of cooperation of the enterprise of communication with other market actors in the process of economic activity, and some others.

Statement of the task of the article. The task of this article is to present the author's vision of the following aspects of this problem:

- clarification of the modern content of concepts;

- research trends changes in the economic activities of telecommunications enterprises in Ukraine;

- representation of the model of interaction of the communication enterprise with other market entities in the process of economic activity.

\section{Clarification of the modern content of concepts}

The modern economic activity of communication enterprises as a result of the introduction of new technologies, increased competition, the globalization of telecommunications service markets, and the impact of other factors is substantially transformed both in content and in form. Therefore, it is useful to clarify, in accordance with the new conditions, the formulation of the basic concepts associated with this problem: economic activity and global markets.

Clarification of concepts is performed by survey methods. 
"Economic activity". There is no generally accepted definition for this concept yet.

The most common formulations are next.

Economic activity is any activity of economic entities aimed at obtaining economic benefits (https: / / studfiles. net/preview/1003463/page:13, 2018).

Economic activity is a set of actions at different levels of management, as a result of which people satisfy their needs through the production and exchange of material goods and services (http://abc.informbureau.com/ html/yeiiiiexaneass aassoaeuiinou.html, 2018).

The authors of the work (Golubev, Stryi, Zakharchenko, 2015; Kling, 2011; Gukasyan, 2003) treat the content of this concept as follows. The term "economic activity" comes from the word "economy" and takes its origins from the "model of an economic man” proposed by Adam Smith. The model describes the behaviour in the market of the main subjects of the market for entrepreneurs and consumers. According to A. Smith, an economic person acts in the market selfishly and rationally. He seeks to maximize profits as an entrepreneur and to maximize utility as a consumer. In the conditions of complete freedom of entrepreneurship, the producer strives to be guided by his own interests. But the laws of the market force him to produce not the products he would like to produce, but only those which are in demand, and sell them at the lowest possible price since only in this case he will be able to surpass his competitors and increase profits. Thus, an entrepreneur may not think about the well-being of society, however, the market forces him to act rationally, as a result of his egoism benefits society, providing abundance in the market for goods and services of better quality and at a lower price. The activity of an economic person in the market is an economic activity (Golubev, Stryi, Zakharchenko, 2015; Gukasyan, 2003).

The economic activity of the enterprise unites all types of work that must be performed to ensure that the target consumer receives the goods and services necessary to him. This is a set of actions, operations, work (business processes), the implementation of which leads to the receipt of an appropriate set of products or services that can meet certain needs and can be a product of exchange. The economic activity becomes profitable when the market has a certain effective demand for goods and services that the enterprise can offer (Golubev, Stryi, Zakharchenko, 2015).

Thus, the economic activity of the enterprise includes all types of processes and works aimed at the production and supply to the market of goods and services that are recognized by consumers as useful and for which there is (or may be) demand. It should be noted that in global markets, communications companies can offer the market the newest products not known to consumers and for which demand needs to be formed. This is one of the features of the economic activity of communication enterprises (as well as other enterprises) in global markets.
"The Global Market". The problem of the globalization of markets began to be studied by researchers after the publication in 1983 of T. Levitt's book "Globalization of Markets", the main idea of which is to affirm that all people living on the planet are more likely to have a similarity than a difference. Modern communication technologies contribute to universal and comprehensive universalization - the world turns into one big village. Enterprises can make good money if they, forgetting about differences, focus on the similarity of consumer preferences (Levitt, 2001).

According to Stryi L., the global market is an open market in which enterprises are trying to sell identical high-quality goods, using the same methods of marketing and management; The global market benefits both producers and consumers (Stryi, 2016).

Thus, the modern market for communication services, integrated with the help of cyberspace Internet, is a global market. This market has an all-planetary infrastructure, on which, ideally, every person on the planet can have free access to all world communications and information resources.

\section{Research trends changes in the economic activities of telecommunications enterprises in Ukraine}

The basic information documents that form the basis of the study are the statistical reports of the State Statistics Service of Ukraine, the section "Economic Statistics", the subsection "Information Society", tables "The volume of services sold in the telecommunications and postal communications" for 2004-2017 (State Statistics Service of Ukraine, 2018). In the process of analysis, only those data are used that relate to the investigated problem. Articles were also used (Stryi, Orlov, Zakharchenko, Golubev, Bogatyreva, 2017, Telekom: itogi 2017, 2018; Stryi, Golubev, Bogatyreva, Savitskiy, 2018).

During the period under study, Ukraine's telecommunications developed dynamically. In 2016, the total income of all enterprises of the industry from the provision of telecommunications services was 52366 million UAH (revenue growth compared to 2015 was $3.36 \%$ ). In 2017 , the total income of all enterprises of the industry from the provision of telecommunications services amounted to 55127 million UAH (revenue growth compared to 2015 was $5.27 \%$ ). It is evident that thanks to the introduction of the newest communication technologies in the industry, a favourable environment has developed for improving the performance of the economic activity.

According to the terminology of the State Statistics Service of Ukraine, telecommunication enterprises provide consumers following types of services:

- fixed telephony services (urban, rural, long-distance and international communication); 
- mobile communication services;

- satellite communication services;

- internet services;

- other services.

In the future, three types of services will be considered in the analysis of the survey results:

- telecommunication services;

- internet services;

- other types of services.

Telecommunication services include fixed-line services and mobile communication services.

The term "Internet services" was first used in statistical information in 2016. In previous years, the State Statistics Service of Ukraine in the section "computer communication" in a separate line showed "Internet access services". Therefore, in this article, the semantic content of "Internet services" is understood as communication activity for connecting a terminal (computer, smartphone, and any other device) of a consumer to the Internet.

The distribution of incomes of telecommunications enterprises by types of services in the period of 2015-2017 is presented in Table 1.

Table 1

Distribution of incomes of telecommunications enterprises by types of services, 2015-2017, $\mathrm{mln}$. UAH

\begin{tabular}{|l|c|c|c|}
\hline \multicolumn{1}{|c|}{ Types of services } & 2015 & 2016 & 2017 \\
\hline Telecommunication services, including: & 41081 & 40595 & 41264 \\
\hline mobile communication services & 33206 & 34077 & 35217 \\
\hline fixed line services & 7885 & 6518 & 6047 \\
\hline Internet services & 7144 & 9102 & 10818 \\
\hline Other types of services & 2431 & 2669 & 3045 \\
\hline All types of services & 50666 & 52366 & 55127 \\
\hline
\end{tabular}

Source: own research on the basis of (State Statistics Service of Ukraine, 2018)
Figure 1 shows the dynamics of changes in the share of revenues of the main types of services in 2014-2017.

From the graphs in Fig. 1 it can be seen that in the process of introduction of the newest technologies began the redistribution of income shares by types of services. The share of revenues from the provision of telecommunications services in 2016 decreased by $3.58 \%$ compared to 2015 , in 2017 - by $2.87 \%$ compared to 2016 . For two years, the decline was $6.45 \%$.

The share of revenues from the provision of Internet services increased in 2016 by $3.28 \%$ (compared to 2015 ), in 2017 - by $2.24 \%$ (compared to 2016). In two years, the growth in the share of revenues from the provision of Internet services amounted to 5.52\%. There is a redistribution of the share of revenues from the provision of telecommunications services in favour of Internet services.

The same conclusion regarding the research of the results of 2016 is made in the article (Stryi, Orlov, Zakharchenko, Golubev, Bogatyreva, 2017). This means that the situation of "improving the effectiveness of economic activity" from the introduction of new technologies is becoming sustainable.

The reasons for this development of this trend are the following. Due to the price and technological reasons, Internet services were provided mainly by specialized telecommunications companies - Internet providers. After the introduction of the newest technologies by enterprises, the connection to the Internet became available with the help of smartphones, tablets, and other mobile communication devices. Internet services began to provide (and receive additional revenue), most mobile companies. With the growth in the number of Internet users, the introduction of $3 \mathrm{G}, 4 \mathrm{G}$ technologies by telecom operators, the improvement of the mobile Internet, the demand for Internet services and, accordingly, the profit of enterprises from providing these services will grow.

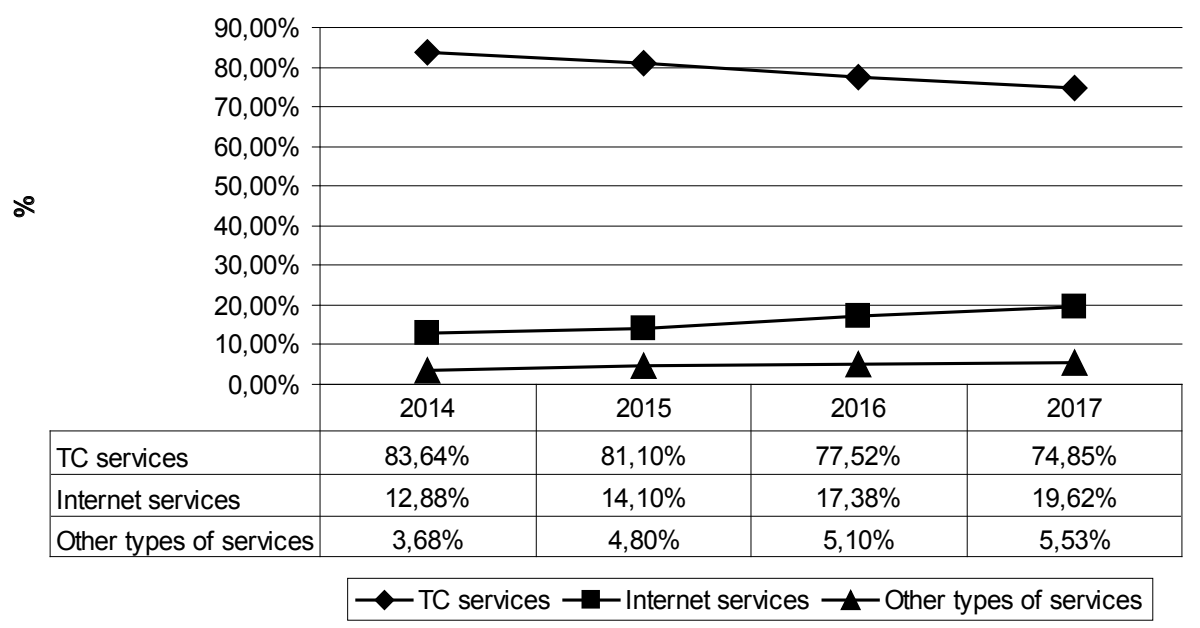

Figure 1. The dynamics of the change in the stake of income of types of services

Source: own research on the basis of (State Statistics Service of Ukraine, 2018) 
After the introduction of these new technologies, Internet users in Ukraine have great opportunities to receive infocommunication services.

Infocommunication services - a relatively new phenomenon in the economy. Infocommunication services have made it possible to more effectively meet the continuously growing needs of people in a variety of information and modern information products that arise in their economic and other activities. The formation of the information service begins with the consumer, accessing the Network with the help of his provider, finds an Internet company (intermediary), and formulates the requirements for the information product that he needs. The Internet company (intermediary) communicates with the manufacturer of the information product or (in most cases) with the enterprise that replicates the information products. After solving the issue of payment, the consumer receives the product he needs directly to his terminal. In more detail, this trend is considered in (Golubev, Stryi, Zakharchenko, 2015).

After the introduction of the newest technologies, the desire of telecommunication enterprises to increase profits through the production and distribution of their own infocommunication services has emerged.

The most common are the following infocommunication services which communication companies seek to provide to their customers:

- interactive television;

- a variety of video products (films, radio broadcasting, concerts, karaoke and much more);

- IP-telephony;

- software.

The range of infocommunication services, which communication companies strive to provide to their customers, is continuously expanding, the quality of services is growing. The demand for these services is stable. The additional profit of enterprises from the provision of these services is also stable. This is a promising direction for the development of the economic activity of communication enterprises (Golubev, Stryi, Zakharchenko, 2015).

\section{The model of interaction of the communication enterprise with other market entities in the process of economic activity}

In the global market for telecommunications services, communication enterprises interact with all other market players. At present, the market is in the stage of development and structuring. In these cases, an effective method of his research is modelling using the heuristic anaxiomatizational approach. This approach allows us to make full use of the creative abilities of the researcher, a deep understanding of the essence of the simulated process. At the same time, it also allows you to drop the non-essential in order to focus on the main thing. This reduces the time for constructing the model and the effectiveness of its use by avoiding the formal description of nonessential details and elements (Philosophical dictionary, Ed., I. T. Frolov, 5th edition, 1987).

Driving one of the possible variants of the model (authoring) is shown in Fig. 2. When preparing the model and its description, the information data is used from the following sources (Schwab, 2016; Castells, 2000; Zakharchenko, 2014; Stryi, Zakharchenko, Golubev, 2014).

Consumers of telecommunications services, Internet services, and information and communication services are all Internet users, all organizations, government, culture, education, the army, the entire population, which provides massive demand for these services, steadily growing market demand and more high requirements for the quality and format of these services. This tendency is considered more detailed in the monograph (Golubev, Stryi, Zakharchenko, 2015).

The system of interaction between enterprises of communication among themselves (within the segment of communication services) is a network structure, which is somewhat conventionally shown in Figure 2.

Network organization of economic activity is most effective in the rapidly changing conditions of the modern economy. M. Castells notes that the formation of an information economy and globalization is characterized by the development of a new organizational logic. In his opinion, an effective organizational form of the modern economy is a network enterprise (Castells, 2000). Network organization of markets is characterized by high efficiency of economic activity; it is able to ensure effective interaction of all market participants and rapid adaptation to changes in the external environment (Stryi, Zakharchenko, Golubev, 2016).

The consumer can interact with the communication enterprise in three ways.

Providing communication services (tcs in Figure 2 Traditional mobile and fixed telephony). Currently, communication is the main interaction. Providing these services brings the greatest revenue to businesses.

Provision of Internet services (is in Figure 2 - services of access to the Network). The consumer receives the access channel to the cyberspace of the Network and solves his problems. The income of enterprises from the provision of these services increases, as shown above.

Provision of own infocommunication services (ics). Many communication enterprises, as already mentioned, themselves begin to produce infocommunication services (ics in Figure 2). This is a promising area of cooperation, in which both consumers and communication enterprises benefit. However, the share of revenues from the provision of these services is still small.

Producers, brokers, and distributors of information products act continuously expanding a number of different companies: internet companies, enterprises 


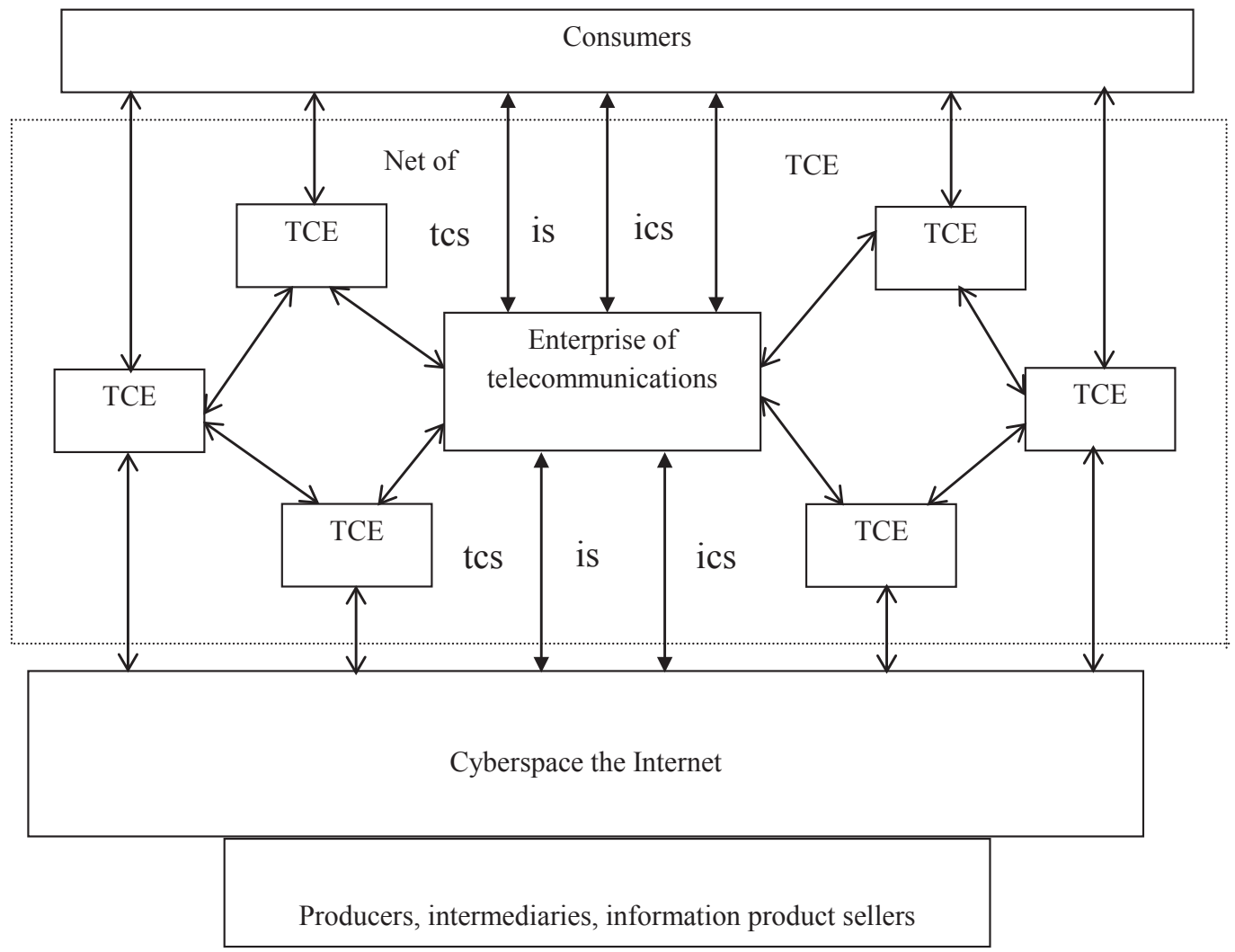

Legend: TCE - enterprise of telecommunications; tcs - telecommunication services; is - internet services; ics - infocommunication services.

Figure 2. Model of interaction of the enterprise of communication with other market actors in the course of economic activity

Source: own development

producers of information products, enterprises, duplicating information products, business intermediaries, enterprises distributors, media businesses and other (Stryi, Zakharchenko, Golubev, 2014; Stryi, Golubev, Zakharchenko, 2016).

This model (Figure 2) reflects the actual structure of communication enterprises' interaction with other participants of the global market and can be used by other researchers to solve various aspects of the study of the modern global market where telecommunications enterprises operate.

\section{Conclusions}

The study of the problem of the impact of the newest information and communication technologies, as well as their convergence on the development of the economic activity of telecommunications enterprises in the conditions of global markets, makes the following conclusions.

1. The notions "economic activity" and "global market" are specified. The economic activity of the enterprise includes all types of processes and works aimed at the production and supply to the market of goods and services that are recognized by consumers as useful and for which there is (or may be) demand. It is noted that the modern market for communication services, integrated with the cyberspace of the Internet, is practically a global market. This market has an allplanetary infrastructure, on which, ideally, every person on the planet can have free access to all communications and information resources of cyberspace Internet.

2. The conducted studies confirmed the assumption that in the process of introduction of the newest technologies in the economic activity of telecommunication enterprises, there is a redistribution of incomes. The share of revenues from the provision of telecommunications services is declining; the share of revenues from the provision of Internet services is increasing. So, according to the State Statistics Service of Ukraine, in 2015, the share of revenues from the provision of telecommunications services by Ukrainian communication enterprises was $81.10 \%$, in 2017 $74.85 \%$. The share of revenues from the provision of Internet services in 2015 was $14.10 \%$, in $2017-19.62 \%$.

3. To increase the effectiveness of economic activities of telecommunications enterprises, a micro-model of cooperation (micro models of cooperation) of 
a communications enterprise with other market players in the process of economic activity has been developed and justified. The micro interaction model reflects the actual structure of the communication enterprise's interaction with all participants of the global telecommunications market. Practical implementation of the model can contribute to increasing the efficiency of the economic activity of telecommunications enterprises in the context of the introduction of new technologies. The model can also be used by other researchers to study various aspects of economic activity in the real market where telecommunications companies operate.
4. The originality of the results obtained in the course of the study consists of detailed study of the real trends in the changes in the content of economic activities of telecommunication enterprises in the context of the introduction of new technologies, as well as in the development of a micro model for the interaction of the telecommunication enterprise with all other market actors.

As further directions of research on this problem, it is possible to recommend studying the changes in demand for services under the influence of regulating price parameters of services in online modes.

\section{References:}

Schwab, K. (2016). The Fourth Industrial Revolution. Retrieved from: https://eksmo.ru/book/chetvertayapromyshlennaya-revolyutsiya-ITD819325

Kotler, P., Keller, L. (2014). Marketing menedzhment [Marketing Management] (14nd ed., rev.). St. Petersburg: Piter. (in Russian)

Drucker, P. (2007). Zadachy menedzhmenta v XXI veke [Management challenges in the XXI century]. Moscow: Alpina Business Books. (in Russian)

Castells, M. (2000). Informatsionnaia epokha: economica, obshchestvo i cultura [Information age: economics, society and culture]. Moscow: Vushchaia schkola economicy. (in Russian)

Kuzovkova, T., Tymoshenko, L. (2016). Analiz i prognozirovanie razvitia infocommunikacatsiy [Analysis and forecasting development of infocommunications]. Moscow: Goriachaia linia-Telecom. (in Russian)

Golubev, A., Stryi, L., Zakharchenko, L. (2015). Ekonomika i upravlenie na predpriatii: osnovnue tendtncgii razvitia [Economy and management of an enterprise: the main trends and problems of development]. Saarbrucken: LAP Lambert Academic Publishing. (in Russian)

Kling, A. (2011). What is Economic Activity? Retrieved from: http://econlog.econlib.org/archives/2011/02/ what is_economi.html

Stryi, L. (2016). Globalnaya ekonomika: sovremennoye sostoyaniye globalnykh rynkov [Global economy: the current state of global markets]. Naukovyy visnyk Khersonskoho derzhavnoho universytetu, 18(2), 92-95.

Gukasyan, G. (2003). Ekonomicheskaya teoriya: problemy «novoy ekonomiki» [Economic theory: the problems of the "new economy"]. St. Petersburg: Piter. (in Russian)

Levitt, T. (2001). Globalizatsiya rynkov [Globalization of markets]. Klassika marketinga. St. Petersburg.

State Statistics Service of Ukraine. Retrieved from: http://www.ukrstat.gov.ua

Stryi, L., Orlov, V., Zakharchenko, L., Golubev, A., Bogatyreva L. (2017). Enterprises of telecommunications in Ukraine: research of the present state and directions of development. Technology audit and production reserves, 4/4(36), 15-21. doi: http://dx.doi.org/10.15587/2312-8372.2017.108664

Telekom: itogi 2017. (2018). Retrieved from: https://nv.ua/techno/it-industry/telekom-itogi-2017-3g-gonkikievstara-vodafone-i-lifecell-ukraina-zhdet-4g-i-mnp-2406286.html

Stryi, L., Golubev, A., Bogatyreva L. \& Savitskiy (2018). Marketynhovyy analiz rynku posluh mobilnoho zvyazku $\mathrm{v}$ umovakh vprovadzhennya novitnikh tekhnolohiy [Marketing analysis of the market of mobile communication services in the conditions of introduction of the newest technologies]. Infrastruktura rynku, 17, 88-94. Retrieved from: http://www.market-infr.od.ua/uk/17-2018

Zakharchenko, L. (2014). Model protsessa ekonomicheskoy deyatelnosti sovremennogo predpriyatiya [Model of the process of economic activity of a modern enterprise]. Naukovyy visnyk Khersonskoho derzhavnoho universytetu, 9(4), 97-101.

Philosophical dictionary. Ed. I. T. Frolov. 5th edition. (1987). Moscow: Politizdat. (in Russian)

Stryi, L., Zakharchenko, L. \& Golubev, A. (2014). Rynkovi mekhanizmy i struktury ekonomiky infokomunikatsiynykh posluh [Market mechanisms and structures of the economy of infocommunication services]. Ekonomika: realiyi chasu: naukovyy zhurnal, 1(11), 134-141. Retrieved from: http://economics.opi.ua/ files/archive/2014/nl.html

Stryi, L., Golubev, A., Zakharchenko, L. (2016). Model setevoy organizatsionnoy struktury gorizontalnoy korporatsii $\mathrm{v}$ infokommunikatsiyakh [The model of the network organizational structure of a horizontal corporation in infocommunications]. Ekonomika: realiyi chasu: naukovyy zhurnal, 6(26), 114-121. Retrieved from: http://economics.opu.ua/files/archive/2016/n4html 